\title{
Making a Difference in Education through Built Environment Education
}

\author{
Hacer una Diferencia en la Educación a través de la Educación \\ Ambiental Construida
}

\section{Fazer a Diferença na Educação através da Educação Ambiental de Construção}

\author{
Mina Sava ${ }^{1 *}$ \\ Vera Marin ${ }^{2}$
}

\author{
${ }^{1}$ De-a Arhitectura Association. ${ }^{2}$ Urban Transition Association
}

\begin{abstract}
The present text is a testimony about the beliefs and actions of a group of people which grows bigger every year, related to the built environment education in Romania. By giving information and tools for understanding the environment we live in, the people are better equipped to make choices, to analyze a specific situation, to avoid being tricked. In this way, it is a path towards more social justice. The history of this group is not long: it has started only 5 years ago. Moreover, the story is told by two of the members of the group (registered as NGO 3 years ago). So, do not expect an academic, objective text based on carefully designed research with lots of data collected and analyzed, but more of an essay about principles, ideas, about ways of making a difference in the education system. Every child has the right to know about the complex processes that transform the built environment he or she lives in. This kind of education is reinforcing the ideas of being part of the society, contributing, showing respect for the heritage, for the others, and develops the children's creativity, critical and practical thinking.
\end{abstract}

Keywords: Education, Environment, Volunteers, Architecture.

\begin{abstract}
El presente texto es un testimonio sobre las creencias y acciones de un grupo de personas que crece cada año, relacionadas con la educación ambiental construida en Rumania. Al dar información y herramientas para entender el ambiente en el que vivimos, las personas están mejor equipadas para tomar decisiones, para analizar una situación específica, para evitar ser engañadas. De esta manera, es un camino hacia una mayor justicia social. La historia de este grupo no es larga: ha comenzado hace sólo 5 años. Por otra parte, la historia es contada por dos de los miembros del grupo (registrado como ONG hace 3 años). Por lo tanto, no esperen un texto académico y objetivo basado en una investigación cuidadosamente diseñada con una gran cantidad de datos recopilados y analizados, sino más bien de un ensayo sobre principios, ideas, sobre maneras de hacer una diferencia en el sistema educativo. Cada niño tiene derecho a conocer los procesos complejos que transforman el entorno construido en el que vive. Este tipo de educación refuerza las ideas de ser parte de la sociedad, contribuyendo, mostrando respeto por el patrimonio, por los demás, y desarrolla la creatividad de los niños, el pensamiento crítico y práctico.
\end{abstract}

Descriptores: Educación, Medio ambiente, Voluntarios, Arquitectura.

*Contacto:mina@de-a-arhitectura.ro

ISSN: 2254-3139

www.rinace.net/riejs/

revistas.uam.es/riejs
Recibido: $\quad 10$ de diciembre 2016

$1^{\text {a }}$ Evaluación: 21 de enero 2017

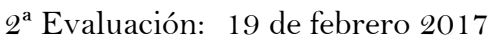

Aceptado: $\quad 11$ de marzo 2017 
O presente texto é um testemunho sobre as crenças e as ações de um grupo de pessoas, cada vez mais numeroso, relacionadas com a educação ambiental na Romênia. Dando informações e ferramentas para a compreensão do ambiente em que vivemos, as pessoas estão melhor preparadas para tomar decisões, para analisar uma situação específica ou para não serem enganadas. Desta forma, é um percurso para uma melhor justiça social. A história deste grupo não é longa: começou há apenas 5 anos e é contada por dois dos membros do grupo (registrado como ong há 3 anos). Portanto, não se trata de um texto acadêmico e objetivo baseado numa pesquisa cuidadosamente preparada com muitos dados recolhidos e analisados, mas mais um ensaio sobre princípios, ideia e, sobre maneiras de marcar a diferença no sistema educacional. Toda a criança tem o direito de conhecer os processos complexos que transformam o ambiente construído em que vive. Este tipo de educação reforça a ideia de ser parte da uma sociedade, contribuindo, mostrando respeito pelo patrimônio, pelos outros, além de desenvolver a criatividade das crianças e o pensamento crítico e prático.

Palavras-chave: Educação, Ambiente, Voluntários, Arquitetura.

De-a arhitectura cultural program activities are partially financed by the Chamber of Romanian Architects (OAR) and the Union of Romanian Architects (UAR), through the funds of the "Architecture Stamp Tax".

\section{About De-a arhitectura}

"De-a Arhitectura" Association is a Romanian organization of architects and teachers established in 2013. The group founding members have worked together since 2011 on "De-a arhitectura" cultural program, a small cultural project of the Chamber of Romanian Architects, Bucharest branch, but in 2 years it became a national network.

The name is difficult to translate: "De-a arhitectura" is a Romanian wordplay, that approximately means "let's play the game of architecture". "De-a ..." is an expression that children use when they name or discuss what game to play. And we all know that the best way to learn is by playing. The name does not only appeal to children, it appeals also to architects, being similar to Vitruvius De arhitectura. But the most important thing is that it suggests a game. And games have rules. Because "De-a arhitectura" team dream of a world where everybody is aware of the written or unwritten rules of the build environment and have a built environment common sense. These are the best tools to make better living places in the future.

The idea to start with the build environment education in schools was present in the thoughts of many fellow architects. Many have thought of counting on the education system in order to ensure that the future generations will be more informed and more prepared to produce better living places. But, to make it happen, the first step was to transform built environment content into teaching materials with simple language and easy to use and attractive exercises. The next step was to make sure that this teaching material will be used in schools, and not just in a few schools and not just for a few years. This challenge was not obvious to the group at the beginning. It implied the construction of a whole system that includes, beside the teaching materials, also training methods for teachers and built environment professionals who want to go in the schools, human resources skills, financing tools and project management, communication and public relations activities, knowledge about the education system and its stakeholders. The group had to learn from doing and to build up a strategy for growth and for insuring continuity. 
During this half a decade, the team have worked with children, teachers, parents, but also with architects, planners, designers and landscape designers. Three educational programs for schools have been created and applied for different age groups. Along with this programs for schools were developed conferences for children, on architecture and creativity and various workshops, some in connection to architectural and urban events or for art museums. To support all this activities the team realized that they needed well trained people, good educational tools and money, so they have to do: training courses for teams of teachers and architects, completed with conferences on this topics, research teams for new projects and also fundraising projects.

Each person of the initial team or who joined afterwards has done some reading in the field of pedagogy or on the relationship between the built environment and wellbeing of people. Some people of the team are part of academia. But, this team is more focused on doing than on the theoretical approach. Hopefully there will be some research projects that would help the group to better evaluate the impact of the courses on the children, their parents and grandparents, or the teachers.

In the initial phase, the mission of "De-a arhitectura" was "to bring architecture education in schools, in order to open the children's eyes to the values and complex issues of the built environment". After 5 years of intensive working with children, teachers, architects, parents, education institutions, etc., the team has rewrote the following mission statement which takes into consideration three categories of important stakeholders: the beneficiaries (children, adults), the partners among the built environment professionals, but also the partners that are to be found among the professionals in the education who are in great need for changing their teaching methods.

\section{We build with education. Our construction grows when: \\ - The children and the adults understand and cherish built environment values and they are active members of their communities in which they share places. \\ - The built environment professionals are involved, through education, in the society. \\ - In education, playing, experimenting and being creative are taken serious.}

\section{The need to know about the built environment}

The Romanian battle for a better living (built) environment is fought against ignorance! No matter the problems they are faced with, the places where we live can only make sense if they are also occupied culturally, and the design which matters is in fact the one which establishes emotional connections between the subject (individual or community) and space. These begin with knowing and acknowledging the space connected rights and obligations of citizens, civil society organizations, public administration (elected representatives and civil servants), and businessmen. On this front of the battle against ignorance, the objective is not to invent the tools (they exist already), but to raise awareness and to unlock the consciousness of adults and children alike. This is the only way to achieve a level of understanding of the processes of transformation of the built environment. And those who do understand these processes are better equipped to act in the future, to adapt in a world of uncertainty, to help balance the forces that make the built environment: users' needs for comfortable spaces, the desire to act to generate economic profit, governance rules and responsibility to provide quality public services. 
Architecture is not generally part of the Romanian's culture, even of the most sophisticated. The society does not share the idea that design could contribute to solving or reducing social-economic problems, and does not recognize that well thought design is an intrinsic part of the solution. Deign is not understood as a whole: beauty+utility+resistance, where all the parts work together, instead it is perceived as a fad, a luxury that cannot come before we can solve the other issues (utility and resistance). Whether residents of large, growing cities, or of shrinking cities with no appeal whatsoever, whether in rural villages richer or poorer, people lack models of better living situations. The still existing rural values are disregarded, and this in a country with the highest rural population in the EU.

In the general confusion, many developers have ignored wilfully or through ignorance / indifference, and for a higher profit, basic elements of the comfort of those who buy apartments or houses. After a state controlled economy, the primitivism of entrepreneurship made the neo-liberal model to be embraced by many developers, who met very low resistance until recently.

Local administrations have superficially adopted slogans, lacking a well-rounded understanding of sustainability. European principles are not really assumed, but only mimicked because local officials are still puzzled by the need for transparency in the decision making processes. Ideas such as reducing the carbon footprint are still quite far... There is no clear set of criteria in the public administration to evaluate whether a project is appropriated for a certain location and this leaves too much room for discretionary decisions.

Many people have high interest mortgages for dwellings which are not functional, and that are lacking basic public facilities, etc. There are very few people with clear ideas about how to evaluate new and old real estate. The level of expectations in terms of built environment quality is rather low. Hence, the developers do not have to perform very well. And this is not only about aesthetics, but also about safety aspects that are only formally checked by the entitled institutions. There are no specialized insurance professionals to help in verifying the buildings since insurance is not really compulsory. So, there are lots of tricky situations in which a person has to rely on his or her own knowledge in order to take some very important decisions.

The "average" citizen does not have a say in the transformations of the area he or she lives in. Most of the people do not even know that there is legislation imposing to the local authorities to inform the inhabitants for certain procedures in urban planning. But, unfortunately, very few people make the connection between what they might have learnt in the civic education classes and the surrounding environment. The children are taught something in school about the role of the elected officials in the local council, but the teachers themselves do not operate these connections about the decisions on local budget and the investments that are made by the municipality in their neighborhood. The physical reality of their day to day life and the mechanisms of democracy are not linked to each other in the minds of adults who were educated during the communist regime. And the children can miss this too because their teachers are this kind of adults.

Besides very pragmatic aspects of this need to understand the built environment, there are also important cultural and political aspects that have to be taken into consideration: the rights to the city, to decent housing, to public facilities have been missing for more than 25 years from the public agenda in Romania. And this is also due to lack of 
knowledge. It is not common sense that evictions could and should be avoided or that homelessness can be decreased through public intervention. The Romanian society passed overnight from everything in the hands of the State to everything to be regulated by the market. There are many losers of this abrupt transition. And there is very little solidarity in the society. Solidarity can be learned. We should learn to care about social justice.

\section{The built environment professionals become involved, through education, in the society}

In Romania, architecture as a profession has gone through brutal changes: from a somewhat privileged group who had missions related to transposing into space the Communist propaganda, all of a sudden the architects became service providers in a context of savage liberalism. Now, there are signs announcing the existence among architects of some forms of social conscience: design themes in partnership with citizen initiative groups, but also volunteers who look into the future and want to prepare the youth to become more aware of the places around them.

The success of the built environment education programs in Romania is mainly due to these volunteers. Just by creating teaching materials or by getting the Ministry of Education approval on the description of an optional course does not necessarily mean that these materials get to the children. On the contrary: there are many optional courses that have this approval but that become forgotten in little time. The teachers do not dare to introduce them in classes by themselves. This is how the idea of volunteers who are constantly helping the teachers has been launched. Without these volunteers (mainly architects, but also planners, designers, landscape architects, engineers), the new optional course would have been ignored by most teachers or regarded as something elitist, too technical or too social.

Each person has a direct experience with the built environment and the children can better relate to geography, history, mathematics and physics when someone is pointing out how these are found in their surrounding world. Moreover, interesting discussions can be inspired by explorations of the built environment through trips and visits. The education exercises and projects that involve hands on activities can turn imagination into reality. But the teachers wouldn't dare to use the built environment by themselves. There was and still is a need for the volunteers. The presence of the volunteer the teacher is making a team with was encouraging the people from the education system to see how this program has a fresh approach. They have realized that it is helping them to demonstrate the use of learning / bodies of knowledge from various other disciplines by applying information to the built environment.

Volunteering was not very common in Romania during the 1990s or even the decade of 2000. During the communist regime, people were forced to do "volunteer work" in the public spaces. The Romanians are learning about the benefits of volunteering. There is more and more interest among young people especially and "De-a arhitectura" Association was offering a frame for the professionals of the built environment who were looking for ways of contributing somehow. This is the explanation for the rapid growth of the network at national level: in less than 2 years, there were classes in the program from all regions of the country. And the network was interesting to volunteers and 
teachers not only in big cities, but also in villages, where many have never seen an architect before.

A volunteer goes to school and teaches in class every week, without any financial retribution. Some of them are in this program for as long as 4 years by now. The hope was that, after 1 or 2 years of teaching this program, along with an architect at the beginning, the teachers will find it easier to do it with less help from volunteers. The reality is that all teachers, even those who are applying the course for the 3rd time, want the architect in the classroom. They bring arguments related to the freshness that the volunteer brings, for the change in the classical teaching process, for the new information.

So every year, more than 150 architects are involved in this teaching process. Around 20 $\%$ are being veterans in the program, and the rest of $80 \%$ have to be trained. That implies a complex registration system, and a training that is organized together with the new teachers. In order to cover all the regions, several local coordination units have been created. Highly motivated people from the local branches of the Chamber of Architects or the Union of Architects have given their time and energy to organize the volunteers and the teachers. These two professional organizations have given not just financial resources, but also recognition and prestige to the initiative.

One important objective for the future is to establish a partnership with the professional organizations in order to obtain official recognition of a new specialization: the built environment professional who is also an educator, capable of facilitating the knowledge transfer and the communication among built environment stakeholders.

Another method of creating links between professionals and children is through the conferences for children where architects are lecturers. It is a real challenge to speak about complicated things in a way that is attractive to children. And there are architects who are willing to take this challenge and present to children, in a format of a short conference, projects they are passionate about. More often than not, this kind of meeting is a child's first exposure to the concept of conference and it becomes a remarkable experience. The age group of 6 to 12 years old is the most active public compared to the 12-16 years old participants. Apparently, the use of virtual reality for older children decreases the curiosity for direct experiences in the real space. That is one of the reasons for which one can say that it is never too early to expose children to the stories told by built environment professionals.

\section{In education, playing, experimenting and being creative are taken serious}

The Romanian education system of today is unfortunately not so much different from the one of the last century. During the communist regime, the access to education was granted and many people were given a chance to live a decent life because they did well in school. Of course, the curriculum was designed for high level of competences in Natural sciences and Math's, but the critical thinking, the entrepreneurial approach, the communication skills were not important. Literature and history were subject to distortions that suited the ideology. Artistic skills were considered as secondary and creativity was encouraged mainly in terms of technical innovation. A lot of reproduction of information given by the professor was expected from pupils. 
Nowadays, the teachers face loss of authority. Doing well in school is not a guarantee for a proper income later on. The information the teachers can give to pupils is also on the internet when it comes to natural sciences. The time and interest of children go to computer games, and not to reading literature. Besides the general crisis in education that was induced by the internet and the speed brought by technology, in Romania, there is also a crisis of societal values related to education. If before 1990 parents were telling their kids to pay attention to teachers and try their best, today, they don't reinforce the teachers' authority anymore. Because of small salaries, many teachers have chosen to leave the education system if they could find other kind of jobs. Being a teacher is not prestigious as it was the case before.

Children from poor families for whom the school could be the key to open the world, don't stand a chance if they meet there only frustrated, resigned teachers! They might get access to technology, but the useful information on the internet will be ignored by them without some basic learning on how to learn. Instead of giving information, the teachers have to become good coaches, with passion about teaching and a variety of topics -to pass this passion on to the children, to get them motivated to reach for knowledge, for understanding.

The educational programs created by "De-a arhitectura" were taking these issues into consideration. With the help of pedagogy specialists (from the Faculty of Pshichology and Educational Sciences of the Bucharest University), the teaching materials are designed to help teachers and volunteers engage and motivate the pupils to explore, to think, to present, to imagine and work in teams to make models through negotiations and handson activities. The pilot applications have proven that teachers are positively influenced by these tools that are designed according to new teaching methods and theories. As a consequence, these aspects became arguments for the teachers in favour of choosing this optional course over others.

"De-a arhitectura" wants to open children's and teens' eyes about their surrounding environment and build a healthy attitude towards the built environment issues. But this can not be done in the rigid ways of instruction, with a professor or an architect giving lectures in front of the class. Built environment shouldn't be just another boring subject in school. The objective is not to ask the children to become little architects, but to help them use their creativity and a problem-solving way of thinking. The design thinking does not exist as an education objective in our schools. And it is so very useful in life.

Built environment is interdisciplinary. Studying it requires an integrated approach. One can talk about the trees we see through the window (biology) and add something about the rhythm of the façade across the street (music) and about the time when the next door church was built (history, religion, visual arts). One finds meaningful connections between disciplines and elements of the surrounding environment. From mathematics to arts, from languages to biology, from social studies to physics, from finance to laws, everything has to be taken into account to create something new in our places. And it is more fun when you create something new with colleagues that have different experiences and abilities than yours.

The approach in the Romanian educational system is still facing a strong separation between disciplines/subjects and only a handful of teachers make the effort to demonstrate the connections with the surrounding reality in what they teach. Logistic conditions for organizing experiments are lacking. Children do not understand why they 
have to learn abstract things. Learning by doing and learning by playing are not used. "De-a arhitectura" is the first interdisciplinary curriculum used in the Romanian schools and is based on project learning and experiential activities.

Architecture and built environment can not be properly understood if they are not experienced directly. In the built environment education program for the 9-12 years old, children have to get out of the classroom to explore. It is still a very uncommon practice for Romanian schools, but an activity that children enjoy a lot. After the trip, when back in the classroom, they talk about their findings in the exploration, and the notions are introduced through their questions and games.

The games are very important and take most of the time in the program. Their topics vary from the most poetic approaches to real life simulations. There are five chapters in the program (for the 9-12 years old) and each chapter is meant to pass a principle: the things from the built environment have to focus on the human needs (scale and proportions chapter), space, light and materials define architecture and all senses count when you experience the built environment (space and materiality chapter), any place has its own features and when you build something new you have to consider the past (place identity / genius loci chapter), the city is like a living organism with rules to help us all live well together (the city as cooperation in space and time), think in a sustainable way every action that you take in the built environment (sustainability of the built environment chapter).

And, surprisingly enough, the volunteers discover very often that these principles are already present with most of the children, like some common sense that we all have when we are very young and that gets lost somehow through segmented education, through social constraints, through too much competition.

At each chapter, the children have tasks that are carried out in workshops, as team work. The last sequence of the program is dedicated to a larger project in which all the pupils of the class contribute to, through building their perfect neighborhood, at a LEGO scale. At the end of the school year, "neighborhoods" from each class in the city taking part in the program are exhibited together. Each class presents its result in a sort of "festival" that can last for 2 weeks if there are many classes in that particular city.

For the younger pupils, 6-9 years old, the approach is slightly different: they have to build imaginary cities / villages based on a fantastic story. The story is meant to help them be more aware that every place has a specificity which is defined by their inhabitants and by the natural context.

Older pupils, 12-18 years old, have to analyze and then think of improvements for their school. The vast majority of Romanian schools are still as obsolete as the educational system. Many school buildings are being renovated but without changes their functionality. They have rows of classes on corridors, concrete courtyards and forbidden green spaces. The overall image is one of a prison. They lack common spaces inside and outside, or peaceful spots where you can study alone or in small teams. The libraries are just shelves with books, but they can not be used as places to read. Very few schools have canteens. Changing rooms for sports are a challenge. There are serious safety issues, and, in some rural areas, decent sanitary facilities are lacking.

The gymnasium and high school level pupils' project is not about solving all the school's problems, but about listing them and, by doing so, becoming aware of the spaces where 
they spend a lot of time in. Furthermore, the pupils are encouraged and helped by the volunteers to come up with some creative ideas that can be implemented by them. The task is to open the eyes of the entire school community about their surrounding environment, but also to find a little thing they can do for real, with a small amount of money, and that can make a difference in their school. For this, they have to analyze, brainstorm, choose, describe (collages, models, make visual and written materials), present their ideas to other school colleagues, teachers, school principals, etc., and get their feedback, adapt the proposal to the feedback, calculate the costs, find financial and material resources, implement the idea. Everything is done in smaller or bigger teams, in which each of the teens gets to know himself/herself better and also their peers who count so much at this age.

\section{Making a difference in education}

The feedback gathered in 5 years has shown that the children begin to see the city with different eyes, to ask questions about their surrounding environment, but they also begin to understand better the built space, the rules of living together, and dream of future cities. They like a lot the explorations, but also "making things with their hands, things that they have imagined". During the school year they become very attached to the volunteers. The most difficult part is to form teams and to work in teams and this is due to the high level of competition in the society, as well as to the lack of teachers' skills to facilitate team work.

In terms of skills and interests of children, in a classroom of around 25 pupils, there are always 2 architects / designers, 4 engineers, one artist, 15 responsible citizens that understand the values of architecture and 3 little persons who are never interested in anything.

"De-a arhitectura" team believes that there shouldn't be a special educational program for different social groups. They all should learn to see, to understand, to reimagine their spaces and to become an active citizen in their community, in the same way.

In big cities, public schools still have children with quite a mixed social background. In villages, the majority of the children are affected by poverty or by lack of good conditions for learning. It is remarkable that the children with poorer background are somehow more interested in the built environment education program. These children are avid of new information and eager to work with people outside the school. In these cases, the school is like a gate to their first encounters with the professionals who volunteer, but also with the other urban stakeholders that they start to understand. In this respect, these educational programs are like an interface between school and the rest of the community.

The volunteers are resource persons for teachers. They volunteer because they believe in this cause. It is about people who have hope, who want to give from their valuable time and knowledge so that, through education, there will be more aware citizens, better chances for the future of our settlements. This fresh energy coming from the volunteers is also influencing the teachers, who need better payment, more esteem from the society, but they are also in great need for enthusiasm, for hope.

All "De-a arhitectura" teaching materials, books and training courses are free for their users in the public schools. The association uses many fundraising methods to make the program available for free to children. The group relays a lot on the pro bono work of its 
members and volunteers. Both the Romanian Union of Architects and the Chamber of Romanian Architects have seen these activities as being very important and "De-a arhitectura" association is helped with financial resources for the projects that are considered by the two professional organizations as strategic for the Romanian society. There was no financial support for the programs from the Ministry of Education, nor from local authorities.

A new kind of education should be free and accessible to everyone as a way to insure that each child will have a place in the society. There is a lot of uncertainty about the future. No one knows today what will be the successful professions in 20 years time. But it is clear that everyone would be better off if he or she is used to critical thinking, team work, use of creativity and is cultural and social aware.

\section{Brief CV of the authors}

\section{Mina Sava}

is architect, graduated from the University of Architecture and Urbanism "Ion Mincu" of Bucharest, Romania in 1996. From 2002 is director of the architecture department of A Still MA, were she won several prizes at architectural competitions. Founding member of the Chamber of Romanian Architects (OAR) in 2003. Founding member, initiator and president of the De-a Arhitectura Association in 2013, the first Romanian team that develops and promotes architecture and built environment education for children and youth in schools. Romanian delegate at the Union of International Architects work program Architecture and Children. Email: mina@de-a-arhitectura.ro

\section{Vera Marin}

has joined the teaching staff of Ion Mincu University of Architecture and Urban Planning and, from the same year, she has been the president of Urban Transition Association where she has also worked as project coordinator, trainer, expert for various topics: participatory planning, housing policies, public spaces, heritage protection, legalizing of informal settlements, urban regeneration, local cultural policies. In 2004, she established as a partner a new architecture and urban design studio. From 2011, she is active with the built environment education group which registered as an NGO in2013 under the title De-a Arhitectura. In this new association, she issuing her previous research and teaching experiences as well as her entrepreneurial skills to promote innovation in the education system in Romania. Email: vera@de-a-arhitectura.ro 